\title{
Symbols of Emancipation? Images of God/dess, Devotees and Trans-sex/gender in Hindu Traditions
}

\author{
Birgit Heller
}

From Ancient times the imagery and mythology of the most important Hindu gods Viṣnu and Śiva - who are personified as males - comprise well-known and popular representations of transsexual/transgender phenomena. For special purposes, Viṣnu takes on a female form called Mohin̄, whereas the androgynous manifestation of Śiva as Ardhanārî́vara unites the male god with his female counterpart. The significance of these images does not remain the same throughout history. The varying interpretations change according to different cultural contexts, developments, discourses and interests. Regarding Viṣnu Mohin̄ī, she may represent the classical stereotype of the temptress, but can also be considered as a transsexual. Pictorial representations act as powerful symbols which legitimate traditional patterns of sex and gender, as well as their dynamic transformations.

Religion and transformation; gender; Hinduism; Religious Studies; god/dess symbols; transsexuality; transgender; androgyny; fluid sex/gender; queer

Birgit Heller is Professor of Religious Studies at the University of Vienna. Her main research focuses on comparative religion (e.g. death, mourning and afterlife); religious and spiritual dimensions of palliative care; modern Hinduism; gender and religion. Recent publications: Wie Religionen mit dem Tod umgehen. Grundlagen für die interkulturelle Sterbebegleitung (Freiburg/B. 2012); with Andreas Heller: Spiritualität und Spiritual Care. Orientierungen und Impulse (Bern 2014).

\section{Introduction}

Though change of sex and gender reversal are wide-spread phenomena in traditional and modern cultures, ${ }^{1}$ they hold a more than prominent place in the realms of Indian mythology, religion and society. As in most other cultures, the great preponderance of instances of trans-sex/gender phenomena relates to the transformation of a man (a male god) into a woman (or a male androgyne). Today, India belongs to those few countries of the world juridically accepting a third gender. Since 2009, persons who do not define themselves as man or as woman have the possibility to choose the category "other" in official papers and forms.

1 Among the range of studies on different cultures are such titles as Baumann 1955; Bleibtreu-Ehrenberg 1984; Lang 1990; Ramet 1996; Roscoe 2000; Suthrell 2004. 
This development, however, cannot be regarded as a modern innovation, but is linked to the old Indian tradition of a third gender defined by the Sanskrit term tritīy a prakrti (Syed 2003). Nevertheless, there is no reason to be enthusiastic about this apparently open-minded concept. Though the well-documented third gender was regarded as a natural phenomenon in the old Indian tradition, it was explained by medical theory as a product of the poor quality of the elderly "semen" or of their misbehaviour during sexual intercourse (Syed 2003, pp. 74 f.). According to these ideas, parents deviating from sex- and gender-based norms produce children with deficient male sexual organs deviating from the masculine gender-role. ${ }^{2}$ Being neither men nor women, they were regarded as impotent "nomales" without offspring. Persons belonging to the category of the third gender were mocked, treated with scorn and socially marginalized.

In modern sexual theory and in Gender studies as well, the terminology relating to different phenomena concerning sex and gender, is complex and manifold (Johnson 2010; Sigusch 2013). Therefore it is not always easy to discern what is meant by transsexual or transgender, intersexual or intergender, bisexual, fluid/ liquid sex or gender and so on. Moreover, in contrast to earlier presumptions, the distinction between sex and gender has turned out to be not as clear as it seemed to be, the realities designated by these terms are intertwined in many ways and form each other. ${ }^{3}$ As a consequence, sex and gender ambiguity cannot be strictly separated from each other either. Concerning trans-sex/gender symbolism, there are plenty of meanings on mythological, spiritual and social layers. Closely linked are topics such as multiple gender, queer issues, attitudes towards sex- and genderrole (non)conformity, stereotypes of masculinity and femininity, the status of women in general and misogyny in particular.

From ancient times the imagery and mythology of the most important Hindu gods Viṣnu and Śiva - who are personified as males - comprise the well-known and popular representations of trans-sex/gender phenomena. The Hindu concept of the god/dess generally differentiates between a transcendent impersonal aspect without qualities (nirguna) and a specific personification with qualities (saguna). Personified Hindu deities are determined by gender and sexuality, which can change under specific circumstances. For special purposes the male god Viṣnu, for example, takes on a female form called Mohin̄, whereas the androgynous manifestation of Śiva as Ardhanārîśvara unites the male god with his female coun-

2 The terminology makes clear that persons who belong to the category of the third gender are understood as "no-males", whereas women deviating from the social or anatomical norm are also known but hardly mentioned (Syed 2003, pp. 75 f.).

3 Regarding the historical development of gender studies, in the 1980s, sex and gender were used as terms designating the biological and socio-cultural dimensions respectively. The distinction between sex and gender in terms of nature versus culture was put into question in the 1990s. For the application of gender analysis in the context of religious studies cf. for example King 2005; Bowie 2005; Franke / Maske 2012. 
Symbols of Emancipation?

terpart Pārvatī. However, the significance of these images does not remain the same throughout history. The varying interpretations change according to different contexts, developments, discourses and interests. Pictorial representations act as powerful symbols which legitimate traditional patterns of sex and gender, as well as their dynamic transformations. This article tries to demonstrate that the complex Hindu god/dess symbolism corresponds to the socio-cultural norm of the binary sex/gender-code, but also has the potential to put it into question and empower social transformation.

\section{The Androgynous Godhead}

The androgyne is defined as a creature simultaneously male and female in physical form (O'Flaherty 1980, p. 283; 2005, p. 337). In the History of Religions the term androgyne is the most common name for a phenomenon sometimes called hermaphrodite or bisexual ${ }^{4}$ god (Baumann 1955). This concept usually refers to a god. It is not universal but widespread and reaches far back into religious history. Different visual images of the half male and half female figure can be distinguished as follows: Sometimes the border-line is running horizontally, but most times the figure is divided vertically with one side, usually the left, bearing a breast. Mythology discerns between good and bad androgynes and allows for the taxonomy of many different types of androgynes, among others socalled splitting and fusing androgynes, which originally appear in the context of creation myths (O'Flaherty 1980, pp. $290 \mathrm{ff}$.). Whereas the splitting androgyne is mostly connected with creative activity by means of (self-)separating a primordial androgyne into a male and a female half, the fusing one must bring an isolated male and female together in order to create. At first sight, the fusing androgyne represents a symbol of union, commonly interpreted as the merging of complementary opposites, the so-called hierogamy (sacred marriage).

\section{1. Śiva as Ardhanāriśviara}

The iconic motif of the so-called Ardhanārīśvara is linked with the godhead Śiva, who is regarded as the supreme Indian androgyne (O'Flaherty 1980, p. 310). This form played a fundamental role in the early development of Śiva imagery and theology: Earliest images date back to the first centuries C.E. (Bisschop 2009, p. 750). Presumably about the same time a large number of explanatory myths and

4 According to modern sexual theory the term "bisexual" defines the sexual orientation (and practice) of a person including partners of both sexes (Sigusch 2013, pp. $363 \mathrm{ff}$.) and is therefore no longer applicable for a person combining male and female traits. 
narratives evolved. Especially the Purāṇas, but also folk traditions refer frequently to Śiva as the androgynous God. The sacred image of Ardhanārīśvara is universal in India, although variations of its characteristic features can be found. As it is evident from the prevalence of sculptures all over the country, the image has to be regarded as one of Siva's most popular forms (Yadav 2001, p. 9). It is out of the question that the Ardhanārīśvara represents a form of Śiva bestowing a different status on the male and the female deities fused in this composite image. The name Ardhanārīśvara itself is a masculine noun for a male androgyne.

\subsection{Iconography}

The iconographic descriptions of Ardhanārīśvara convey distinctive diagnostic features of the image across time and place, thereby constructing a coherent tradition of a standard pattern. ${ }^{5}$ Dissimilar earrings rank among the most common diagnostic emblems demarcating the dual nature of the deity. There are some damaged sculptures which can only be identified by this indicator. A few features, such as ornaments, rings or belts, are shared jointly by the male and female sides, others like garments, hairstyles and colours differ. The right half of the image is usually male; the left half of the image female. Apart from rare exceptions, they share one face. The male and female halves show differences in the presentation of the body. The male half displays male physique, including flat chest, broad right shoulder, wider waist, and a more massive thigh; on North Indian images sometimes also half a phallus is found. The central physical feature of the left half is a woman's well-developed breast, the waist is smaller and the hip fuller than the corresponding male half of the body. An important feature is the number of arms varying by two-armed, three-armed and four-armed forms. Whereas Siva is often depicted with the triśüla, the trident (his weapon par excellence) or an axe, Pārvatī holds a mirror, a flower or a parrot in her hand. Moreover, Śiva is singled out by specific mudrās, gestures, expressing particular symbolic messages like the assurance of fearlessness or bestowal of favors onto the devotee. Śiva's third eye, the symbol of wisdom, can also be constructed in different ways: most times as full or half eye situated on the forehead of the male half or in the middle of the forehead, corresponding with the full or half female bindu or tilaka, the sign of the married wife or as full eye shared by both sides in the middle of the forehead.

The iconographic features make it abundantly clear that Ardhanārīśvara images convey religious significance in a language that is biased against gender (Goldberg 2002, pp. 24, 54). Although the images vary in the degree to which gender hierarchy is present, the advantage is primarily placed on the right-male side. In Indian culture, the left-hand position usually is associated with something

5 Cf. the detailed Iconographic descriptions in Yadav 2001, pp. 19-30 and Goldberg 2002, pp. 11-16. 
Symbols of Emancipation?

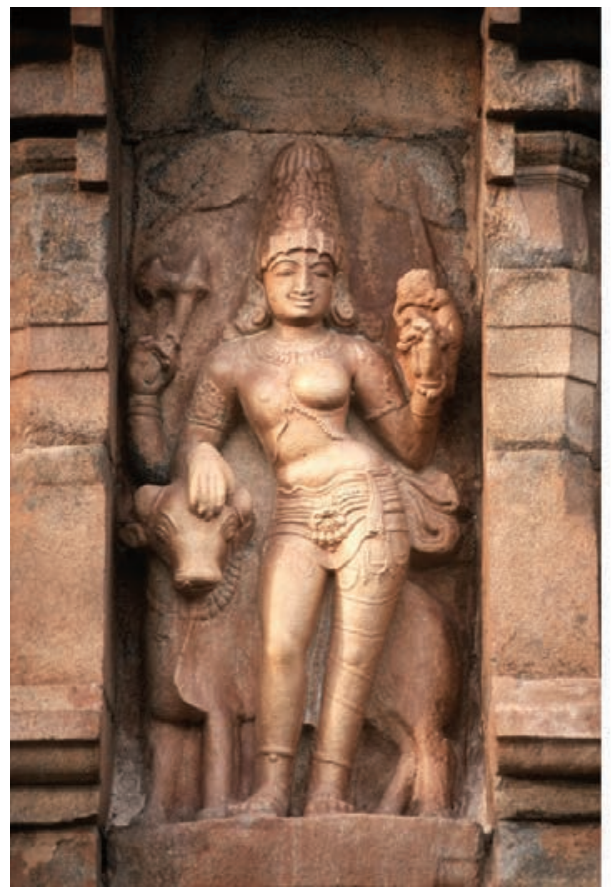

Illustration 1: Ardhanārīśvara, three-armed bearing an axe and a parrot respectively, $11^{\text {th }}$ century, Brihadeshwara temple in Gangaikonda Cholapuram, Tamil Nadu, India; (C) Dinodia Photos / Alamy Stock Photo.

low, with weakness and degradation (Goldberg 2002, p. 54; Kalidos 1994). Being situated on the culturally designated dominant right side, the male half of the androgyne is put in a position of authority and privilege (Goldberg 2002, p. 95). In addition, the female identifiers, being associated with domestic life (bindu), sensual love (parrot) and feminine vanity (mirror) impart a secondary status on the female half.

\subsection{Meanings}

\subsubsection{Cosmic Symbol of Creation}

The ancient Vedic mythology relates to several splitting androgynes (or pregnant males respectively) performing the cosmogonic act by separating themselves into two halves (O'Flaherty 1980, pp. 310 f.; Kramrisch 1981, pp. 208 ff.). Numerous myths in the Purānas tell about Śiva giving rise to creation in the form of a splitting androgyne (Kramrisch 1981, pp. $200 \mathrm{ff}$.), thus building on the Vedic tradition, but Siva is also presented as a fusing androgyne giving rise to creation through the (re)union of his two sides. The idea of creation by the union of two complementary 
sides rests upon the Sāṃkya philosophical background (Bisschop 2009, p. 750). The cosmic concepts of the male purușa, the transcendent, conscious subject overseeing creation and the female prakrti, the material matrix and active agent of creation are identified with Śiva and his female Śakti, mostly Pārvatī. In several medieval narrative and poetic texts both are praised as parents of the universe, but other texts lay emphasis on Śiva representing the single cause of the universe by the union of the sexes (Yadav 2001, pp. 113 ff.). The latter motif indicates a clear hierarchical relation between Śiva and Pārvatī, which is the case with the concepts of purus a and prakrti as well. The term puruṣa refers to the transcendent, spiritual reality, which is more highly esteemed than materiality. The same holds true for the symbolism of light and darkness signifying creative forces assigned to Śiva and Pārvatī respectively. The idea of creation as sexual intercourse presupposes Śiva's sending out of himself the woman in him as female manifestation (Pārvatī, Satī, Prakrti) and the following reunion (Kramrisch 1981, pp. 239, 244).

\subsubsection{Symbol of Non-Duality and Liberation}

The foremost religious significance of the androgynous image refers to self-realization and the attainment of ultimate liberation from the cycle of rebirth. The merging of the male and female is used as a symbol of non-duality, denoting the conquest of death and the achievement of immortality (Goldberg 2002, pp. $58 \mathrm{f}$.). In the Hathayoga tradition, the image allows the practitioner to gain selfknowledge and encodes a description for attaining spiritual emancipation. Following the way of Hathayoga implies a process of self-transformation that is accompanied by the deconstruction of gender designations. The historical gendered forms are transcended by realizing the ultimate divine non-duality and the non-dual essence of the self respectively. In the final stage of consciousness the male or female practitioner recognizes himself/herself as Ardhanārīśvara. Thus basically presenting an emancipatory paradigm transforming sexuality and gender, the inscribed gender ideology sets limits to the emancipation of women. Although female adepts are not excluded from the Hathayoga tradition, the treatises have been written from a male perspective for a primarily male monastic or celibate community (Goldberg 2002, p. 82). In Kashmir Śaivism, the mirror in Pārvatî’s hand is interpreted as a means for the self-perception of Śiva, who unites only with himself (Yadav 2001, pp. 134 f.). In the mirror Śiva does not see Pārvatī, but himself. Thus the female side of Siva is simply an instrument for the male's self-recognition and the recognition of the male practitioner's identity with Śiva alike.

\subsubsection{Symbol of Equality between the Sexes?}

Beside its spiritual relevance, down to the present day, the image has been idealized as embodiment of true conjugal love, as a symbol of perfect harmony and equilibrium of Śiva and Pārvatī representing the eternal interdependency of the man-woman unity (Yadav 2001). The Ardhanārīśvara is praised as a symbol of 
Symbols of Emancipation?

equality and balance between the sexes. This position links the modern Indian researcher Neeta Yadav (2002) with several Western Feminists of the first wave from the 1970s onwards. For example Rita Gross was inspired by the androgynous model of deity (most notably in Indian traditions), affirming the necessary shift in basic thought-patterns. ${ }^{6}$ By use of an "androgynous perspective", she wanted to correct the bias of androcentric presuppositions underlying religious traditions and research alike. Under closer analysis, however, the Ardhanārīśvara apparently promising equality and balance, symbiosis and mutuality, often bears testimony to conflict and disequilibrium and turns out to portray an illusion of equality (O'Flaherty 1980, p. 334; Goldberg 2002, p. 112).

Beside myths and folk traditions explaining the image as a result of Siva's passion or love for Pārvatī and vice versa, there are other variants narrating that Śiva merged with his wife Pārvatī preventing her from becoming angry and leaving him (O'Flaherty 1980, pp. 314 ff.). The fusing seems to be motivated by the intention to pacify Pārvatī with the effect to limit or canalize her power. Many stories tell about Pārvatī's conflict with her ascetic husband, who cannot reconcile his two roles: Śiva demands his wife being a yoginī, an ascetic woman, when he performs Yoga, and a käminī, a lustful woman, when he is sexually inclined (O'Flaherty 1981, pp. 210-236). The stories about their conflicts and quarrels are far away from conveying the impression of a perfect loving couple. At least, it is an unusual love, although constant discord and reconciliation may provide a more ardent spur to it. According to a mythical account the androgynous form results from one such reconciliation: One day, Pārvatī decided to desert her husband, who was a beggar and could not care for his wife and children due to excessive smoking (of marijuana). But she changed her mind, begged in his place and returned home. When Śiva came home with an empty begging-bowl, Pārvatī "fed him with the food she had collected, and Mahādeva was so pleased with her that he embraced her violently and became one with her" (O'Flaherty 1981, pp. 234 f.).

On closer consideration the image of the Ardhanārīśvara is a symbol of sexual union, but also represents a situation in which union is physically impossible (being fused inhibits sexual intercourse), thus conquering desire (O'Flaherty 1981, pp. $257 \mathrm{ff}$.). Śiva is the model of the Tantric Yogi turning bhoga, sexual enjoyment, into Yoga leading to ultimate release. Desire is transformed by sexual satiety turning out to be self-control. Within the scope of a correctly performed ritual, the Tantric Yogi indulges in sexual pleasures with a detached mind demonstrating the control of his senses by retaining his semen. It is evident from a medieval poetic text, that the aspect of Yoga, indicating detachment and asceticism, is attributed to the right male side of the Ardhanārî́vara, whereas the aspect of bhoga, signifying worldly affairs and sexual enjoyment, is connected with the

6 Cf. Gross 1977 and many years later she stated: "Nothing would be so salutary as the simplicity and directness of androgynous mythic images and symbols, which would be empowering for both women and men." (Gross 1994, p. 356). 
left female side (Yadav 2001, pp. 122 f.). In this way the image reflects underlying gender-stereotypes putting them into a meaningful hierarchical order. Thus the worldly and sexually inclined woman impeding the spiritual advancement of the Yogi is under control. Concerning the case of Siva and Pārvatì it is obvious, that Pārvatī becomes half of his body, being a part of the "Lord, who is half woman". The name Ardhanāríśvara as well as the iconographic features and the explanatory texts reveal that the image is based on an unequal distribution of power (O'Flaherty 1980, pp. 283 f.). Therefore, it is most likely that the Ardhanārî́vara has never been a symbol of the equality of the sexes (and concerning the hierarchical bias inscribed in the image, not even of their complementarity), but has predominantly served as a tool for the construction or affirmation of normative gender identity.

\subsubsection{Symbol of Fluid Gender}

Western third phase feminism does not glorify the complementarity of the sexes, but challenges the idea that sex and gender identities are natural or (god-)given respectively. Therefore, androgynous images and symbols do not seem to be of great interest any longer. Yet in the course of deconstructing essentialism and modern queer studies, the symbol of androgyny can present an alternative model for fixed gender stereotypes. Taking the discussion further, Ardhanārî́vara might be regarded as a symbol of fluid gender depicting modern queer perspectives which struggle to overcome prescriptive binary gender constructs. Corresponding to this approach is that thread of old Indian tradition interpreting the Ardhanāríśvara as a being beyond all fixed ascriptions (O'Flaherty 1981, p. 252; Syed 2003, pp. $102 \mathrm{f}$.). The Ardhanārîśvara being the cause of the universe is defined as neither woman nor șandha nor man:

O lord of everything, we bow to Thee who art beyond the perception of the sense-organs; who hast no support; who art the support of all; who hast no cause; who art endless; the primordial and the subtle.

All the devas, Viṣnu and others, and the world of mobile and immobile Beings are created by deficient digit with the difference of name and form.

Just as the flames of fire and the rays of the sun emerge and submerge so also this current of creation and dissolution.

Thou art neither a deva nor an Asura, nor a man nor a brute, nor a Brahmin, O lord. Thou art neither a woman nor a man, nor a eunuch [șandha]. Thou makest nothing either the existent or the non-existent.

After all negations whatever remains thou art that. Thou art the maker, the sustainer and the destroyer of the universe; thou art the soul of the universe. We bow to that lord Śiva. ${ }^{7}$

7 Śiva Purāṇa 2.2.58-62. 
Symbols of Emancipation?

The term sandha is translated as "eunuch", but actually means a person of transgender or third gender respectively (see below 2.3.). On the one hand, Siva is characterized as a being beyond definition, but on the other hand, as a being comprising all possible realities in itself. Thus, emphasis is not put on non-duality or gender equality, but on the realization of all possibilities. This notion is stressed by Ruth Vanita (2005, p. 78), who marks an important difference between the emphasis saying that God is neither male nor female and saying that God is male, female, and neuter: "Absence of gender creates a lacuna, which is filled, in worship practice, by the dominant convention of maleness. Conversely, the presence of three genders (male, female, neuter) allows God to be visualized and worshipped as male, female, or androgyne."

Early images of the Ardhanārīśvara present especially integrated forms not only adding up man and woman, but conveying the impression of a completely new and incomparable entity of its own. In contrast to later images, they do not appear as rigidly separated halves put together (O'Flaherty 1980, p. 327), but depict somehow an intersex or intergender being, an individual of fluid gender eluding all attempts of classification. ${ }^{9}$

It is obvious, however, that all these iconographical messages and the texts referring to them focus on theological concerns. What is true for Siva is not easily transferrable to human beings. Therefore only by separating the image from its original rather narrow theological context, it might spread an irritating appeal transgressing all the normative social borders of sex and gender.

\subsection{Devotees and Androgynous Consciousness}

Androgynous consciousness features prominently in different contexts of Hindu spirituality. The Śaiva tradition of Hațhayoga aims at a spiritual transformation overcoming duality of binary thinking into a complete and total unity (Goldberg 2002, pp. $57 \mathrm{ff}$.) For the practitioner of Hathayoga, the iconic form of the Ar-

8 Ruth Vanita argues that ultimately gender is irrelevant to the divine in Indian tradition, though gods and goddesses do have gender when worshipped in iconic form. For her, the "ultimate unreality of gender forms the philosophical basis for numerous stories of sex change that pervade Hindu narrative" (Vanita 2012, p. 742). She tries to differentiate between Hindu and Judeo-Christian or Islamic approaches respectively. Characteristic for the latter is said to be the position that god is neither male nor female, leading to a lacuna, which is filled with the dominant convention of maleness. Hindu divinities, on the contrary, are maintained to have fluid gender and sexuality due to the presence of three genders (male, female, and neuter), allowing for the visualization of god as male, female and androgynous.

9 The terms intersex/intergender and fluid gender belong to the terminology of modern theory of sexuality (Sigusch 2013). 


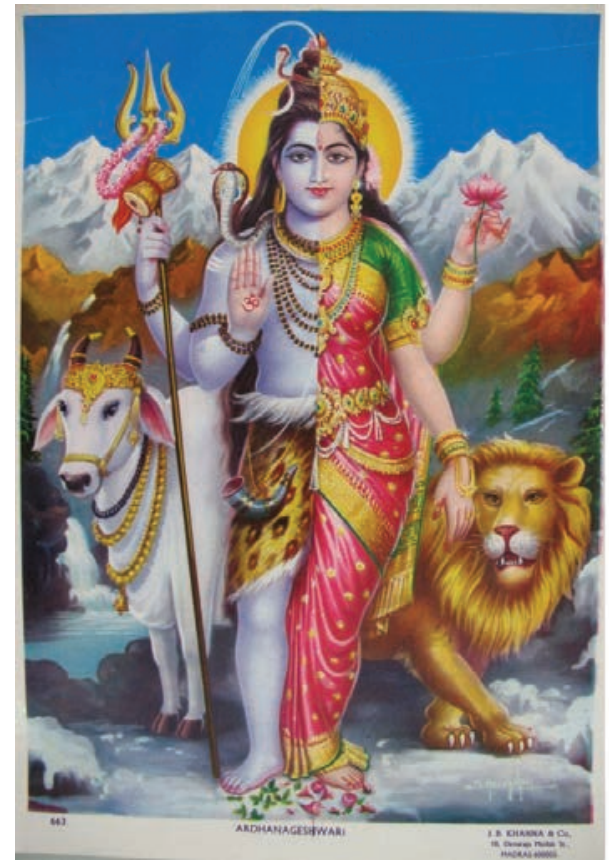

Illustration 2: Modern posters present Śiva and Pārvatī as clearly separated halves. Photo taken by Heike Luu, staff member at the Religionskundliche Sammlung, Philipps-University of Marburg (shelf no.: B-Kp 154 03; original received 1994 from Christa Pieske, Lübeck; through the intermediary of Dr. Vanja, Berlin). Measures: 49.6x34.4 cm.

dhanārî́vara presents a metaphysical paradigm for the nondual cognition of the ultimate reality. Moreover, it functions as a means for self-realization by the process of identification with the deity. The Ardhanārīśvara embodies the formula for spiritual liberation supporting the different stages of meditation culminating in the experience of non-duality. Thus the attainment of androgynous consciousness is part of a spiritual transformation leading to a status of ultimate nonduality. In the ultimate stage of consciousness the practitioner realizes himself as Ardhanārīśvara. The image of the Ardhanārīśvara can be regarded as a truly emancipatory paradigm insofar as sexuality and gender are transformed and dissolved in the unity of the nameless and formless supreme reality (Goldberg 2002, p. 75). Nevertheless, the Ardhanārīśvara cannot be interpreted as a symbol for gender equality. Although female practitioners are not excluded from the Hathayoga tradition, the treatises have been written from a male perspective for a primarily male monastic or celibate community and the classical training and patterns of practice are built upon male psycho-physiology (Goldberg 2002, pp. $82,88 \mathrm{f}$.). Female practitioners must rely upon male anatomy and maleidentified experience as the norm because women's bodies are not considered the 
Symbols of Emancipation?

normative models from which to learn the spiritual exercises and practices of yoga.

Androgynous consciousness is not restricted to the spirituality of Śaiva traditions or the icon of the Ardhanārīśvara respectively. In the medieval Vaiṣnava Sahajiyā movement of Bengal, the divine couple, Kṛṣna and Rādhā, is worshipped..$^{10}$ Rādhā plays a crucial role not only as symbol of true love and model for the ideal female devotee, but as mediatrix to the liberating experience (Dimock 1966, pp. 35 f.). The state of ultimate and blissful cosmic unity - represented by man and woman in sexual union - is called sahaja and attained by ritual sexual intercourse. In the Vaiṣnava Sahajiyā thought the unitive cosmic consciousness is realized by returning the divided male and female principles back to primordial reality of sahaja entailing an "innate androgynous state" (Hayes 2011, p. 510). Sahajiyā practitioners identify themselves with Kṛ̣ṇa and Rādhā through ritual means. In the process of liberation, women represent Rādhā and they may be seen as a ritual necessity (Dimock 1966, p. 101). Compared with the medieval "high" Tantric tradition (between the $10^{\text {th }}$ and $12^{\text {th }}$ centuries), where the female part was sublimated and semanticised out of existence (White 2003, pp. $219 \mathrm{ff}$.), women preserved their important ritual function in the Sahajiyā movement until modern times. ${ }^{11}$ Nevertheless, the status of women, besides being an important means for the attainment of the blissful state of sahaja, remains doubtful. ${ }^{12}$ Comparable to the Hathayoga treatises, the Sahajiyā texts reflect a male perspective concen-

10 Although most of the Vaiṣnava Sahajiyā lineages disappeared in the course of the $19^{\text {th }}$ century, there still exist two branches adhering to older beliefs and practices (Hayes 2011, pp. 512 f.).

11 According to the results of recent fieldwork (McDaniel 2012, p. 66), nowadays, Sahajiyā practitioners perform sexual rituals secretly, if at all. In general, they are underground practitioners and most of them deal with alternative constructions of the body, identifying with Kṛ̣na and Rādhā through visualisation, breathing mantras and so on.

12 The somehow enthusiastic notion of Dimock (1966, pp. $99 \mathrm{ff}$.) concerning the status of women in the Sahajiyā movement is not fully validated by recent research, although the focus of investigation was not placed on the role of women so far. Women seem to be understood as Rādhā in human form and Sahajiyā gurus are said to use sexual initiations for female disciples (McDaniel 2012, p. 66), but these facts must not be interpreted as proofs for the high esteem of women. The famous Bengali Vaiṣnavism demonstrates that the prominence of Rādhā must not influence the status of women at all. The prominent saint Caitanya, who was considered to contain Kṛ̣na and Rādhā in his body was a perfect illustration of the Sahajiyā principle of unity in seeming duality. Though the Sahajiyās see themselves intimately connected to the Bengali Vaiṣnavas, but conversely they are considered as heretics. Contrary to the Sahajiyās, Caitanya saw women not at all as personifications of Rādhā, but as at least distracting, at most deluding (Dimock 1966, pp. 36, 45). The Sahajiyā approach is definitely different, but still the position of women remains ambiguous. 
trating on the male quest to spiritual perfection and privileging the male body. ${ }^{13}$ Given the fact that the "femaleness" is equated with the material principle and the "maleness" is equated with the spirit, the bias of the Ardhanārîśvara is repeated. Moreover, there is another point of view mitigating the religious and ritual importance of women: According to Dimock (1966, p. 159), in the Sahajiyā tradition man can easily become a woman, representing "a sort of hermaphroditic creature", male and female, spirit and matter, forming the two sides of his nature. The male Sahajiyā practitioner adopting the so-called gopi-bhāva, the mood of Rādhā, is said to pass "beyond the point at which he needs a woman as an aid to the realization of blissful unity and to reach the point where he can realize it entirely within himself" (Dimock 1966, p. 160). Although there are these clearly malecentered features, this tradition cannot be considered as anti-female (Hayes 2000, p. 316). According to the Sahajiyā system, both men and women can realise their inner divineness and attain the final liberation, which is dependent upon the harmonious interaction between the male and the female principles. Women, in general, are regarded as teachers and at least some of them held the position of a guru.

\section{The transsexual godhead}

The term transsexuality usually refers to the change of sex, either from man to woman or from woman to man. In many cases the sex change rests on the physical transformation of the body, in some cases it implies a change of gender orientation only. The latter may relate to the exterior appearance (as to gender-specific clothing or hair-dressing) and/or to social behavior. In this sense, the phenomena of transsexuality and transgender could be distinguished, but definitions are far from being coherent. Moreover, recent research has fostered the insight that sex and gender have to be regarded as intertwined categories, which cannot be clearly separated from each other.

Many Hindu myths involve either transvestism or sex change. Each of the great gods, Viṣnu and Śiva, is transformed into a female in a famous cycle of myths. In some respect, the transsexual can also be regarded as a phenomenon related to the androgyne, combining the male and female sexes and/or genders not simultaneously in physical form, but referring to both of them and turning back from one to the other.

13 Hayes 2000, pp. 15 f. Dimock (1966, p. 221), being aware of the androcentric perspective of the texts, pleads to forgive the writers their purely first personal concern and emphasises that the theory says that woman is Rādhā also containing Kṛ̣ṇa in herself. 
Symbols of Emancipation?

\subsection{Viṣnu as Mohin̄̄}

The most popular sex change is carried out by Viṣnu taking on the female form of Mohinī. In the famous myth of the churning of the milk ocean, Viṣnu fools the Asuras, the counterpart of the Devas, who have grabbed the elixir of immortality. ${ }^{14}$ They can't keep themselves from surrendering the pot with the divine liquid. Mohin̄ is described as an overwhelmingly beautiful woman bewitching the Asuras. In a recent re-narration, the seductive figure is painted as follows: Viṣnu took the form of the enchantress Mohinī and approached the Asuras, titillating them with her sensuous walk. The Asuras were bewitched by her beauty, besotted by her sultry smile and her voluptuous figure (Pattanaik 2012, p. 69).

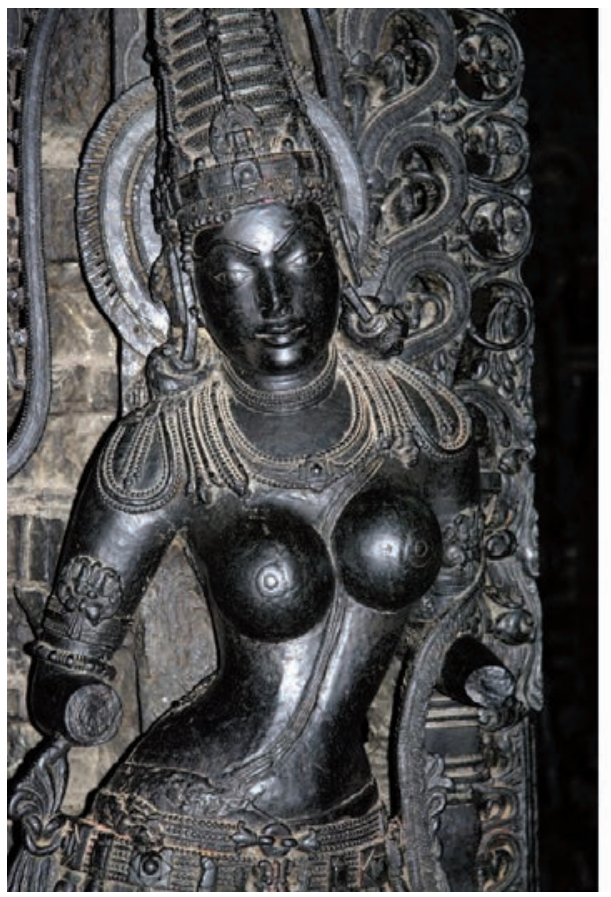

Illustration 3: Viṣnu in form of Mohin̄̄ at Chennakeshava Vishnu temple in Belur, $12^{\text {th }}$ century, Karnataka, India, (C) Dinodia Photos / Alamy Stock Photo.

On the one hand, Mohinī represents the classical pattern of the temptress, she is delusion personified. On the other hand, she can also be considered as a transsexual. For though turning into a woman, Viṣnu never forgets about his male

14 This myth is wide-spread in Epic literature and narrated in shorter and longer versions, cf. O'Flaherty 1975, p. 336. 
identity embedded in his mind. There exists another important myth concerning Mohinī: Śiva, on hearing about this episode, repeatedly requests Viṣnu to show him his fascinating Mohinī form. At last Viṣnu fulfills his desire. The Brahmāṇ̣̣a Purāna at length describes the romantic scenery of a beautiful garden and therein the beautiful woman with every detail of her enticing body. Siva, being fully deluded, seems to have forgotten about her real identity and runs after her:

Siva caught her somehow and embraced her frequently. Shaking him off repeatedly, she too ran far away. Seizing her once again, İ́a [Śiva] who was completely under the influence of the god of Love embraced her impetuously. His semen dropped down then. ${ }^{15}$

\subsection{Meanings}

\subsubsection{Symbol of the Conflict between Sensuality and Spirituality}

A deeper metaphysical significance of the mythic sexual encounter is seen in the illustration of the conflict of this-worldly desires and otherworldly aspirations, of the mundane life and the detached, spiritual life (Pattanaik 2012, p. 76). In normative Hindu traditions, mundane life and sensuality are always associated with women. Thus, the figure of Mohinī reinforces the classical female gender pattern. Mohinī represents the archetype of the seductress impeding man in his spiritual quest. Especially for the ascetic, but principally for all spiritually inclined men, the female-identified sensuality represents a dangerous obstacle on their way to immortality.

\subsubsection{Symbol of Transsexual Homoeroticism}

Since Mohin̄i is in essence a male god, the sexual encounter between Viṣnu and Siva is charged with homoeroticism. ${ }^{16}$ Researchers take different opinions on this subject. Whereas, on one side, it is maintained that traditional Hindu ideas about homosexuality do not support Gay agenda (O'Flaherty 1999, p. 280), on the other, it is argued that those who did not fit in the binary heterosexual framework of society (like the Hijras) created spaces for themselves by retelling traditions which granted power to them (Pattanaik 2012, p. 121). The Indian researcher Ruth Vanita takes the view that the manifold stories about divine sex-changes

15 Brahmāṇda Purāna 4.10.73 f. In the translation of O'Flaherty (1999, pp. 263 f.) the incident is clearly depicted as rape. It is narrated in many texts and different variants (cf. O'Flaherty 1981, pp. 228 f.).

16 O'Flaherty 1999, pp. 264 f.; cf. also the following entries on the internet: Internet sources: Quora; Internet sources: Prabhakar. Devdutt Pattanaik (2012, pp. 16 f.) stresses the metaphysical significance of the narratives and tries to differentiate the metaphysical Hindu view from a Western homosexual interpretation. The cited examples from the internet are Hindu websites, however. 
Symbols of Emancipation?

leading to extensive divine amours had some effect on the discourse about human sexual relations. However, looking at Indian history, it must be stated that, although the awareness for transsexual/transgender people (mostly male femalers who preferred sex with men, Syed 2003, pp. 109 f.) existed from ancient times, these persons were despised and tolerated on the margins of society only. Samesex practices did not attract much attention from the ancient law-givers, but were not estimated either. It is beyond doubt that ancient India was shaped by a heterosexual culture. After all, same-sex behavior was not criminalized, prohibition and penalization of homosexuality started in the colonial-era law and lasts - with a very short reprieve between 2009 and 2013 - till today.

Ruth Vanita (2005,p. 87) points at another quality of the various sex-changes in Hindu mythology: Both permanent and temporary sex-changes are good and enable same-sex desire to be consummated in the form of cross-sex desire. Although modern India is quite reluctant to sex-change from male to female, ${ }^{17}$ Vanita underlines the common feature of all these sex-changes making same-sex desire more socially acceptable by rewriting it as cross-sex desire. But on closer consideration, this hints at a structural problem which can go along with the phenomenon of sex-change. Transsexual people, who decide to change their sex by surgery, ratify the traditional gender order by perfectly reproducing the preferred sex and gender (Sigusch 2013, p. 243). Thus homosexual behaviour is much less disturbing to the framework of heteronormativity.

\subsection{Devotees and Transsexuality/Transgender}

In Hindu traditions, the transformation of women into men is both rarer and seems to be far more destructive than the transformation of men into women (O'Flaherty 1999, p. 281). This fact is traced back to the underlying assumption that the lethal and corruptive essence of woman is increased in a transvestite (phallic) woman. Male-to-Female transsexuals or transgender persons exist in the context of different religious communities, identifying themselves with the female power of a male-personified godhead. For example the Sakhībhāvas, ${ }^{18}$ the "girlfriends" of Krṣna, belonging to the broader context of Vaișnavism, are male devotees taking the part of the female lover. In contrast to other Vaiṣnava traditions describing the relationship between God and the human being in terms of a love affair between a man (the position taken by God) and a woman (the

17 The other way round is viewed as better - in contrast to former times, for even though the transformation of men into women often resulted from a curse, the transformation of women into men was judged to be far more destructive (O'Flaherty 1999, pp. $281 \mathrm{ff}$.).

18 Sakhībhāvas are traced back to the Vaiṣnava poet-saint Haridāsa (1480-1575) and they are said to have been numerous in the $17^{\text {th }}$ century, cf. Johnson 2009. 
position taken by every human being), the Sakhībhāvas do not understand their female role in spiritual terms only. They practice cross-dressing and adjust their behaviour to the feminine gender-role. Moreover, they are said to imitate the physical process of menstruation and some of them are even supposed to have undergone castration. ${ }^{19}$

Much better known Indian transgender people, however, are the hijṛās. Hijra is often used as umbrella term for today's transgender communities of South Asia, Pakistan and Bangladesh (Roy 2014, p. 2). Hijra is the modern term for sexually ambiguous people, who were defined as klības, șandhas or napumsakas in ancient Indian tradition..$^{20}$ Already 3000 years ago, the term klība was used to define a male deviating to some point from the normative male/masculine role: from male anatomy or mental state, sexual orientation or social behavior (Syed 2003, p. 72). In the first centuries C.E. the concept of a trtīya prakrti was developed, designating a third gender besides the male and female genders. Most members of that third gender were anatomical male; rejecting the normative masculine genderrole, wearing women's clothing, jewellery and long hair, imitating feminine behavior. They left their families, did not marry and had no progeny (Syed 2003, p. 63). They were regarded as coward, effeminate and weak, often mentioned in conjunction with the bodily and mentally disabled and despised as defective males throughout Indian history (Syed 2003, pp. 85 ff.).

In contrast to the androgyne of mythological status bestowed with power and dignity, klības were males regarded as suffering from failure, distortion, and lack of sexual functionality (O'Flaherty 1999, pp. 279 f.). ${ }^{21}$ Anyhow, in addition to this fundamental difference, androgynes/hermaphrodites were no more than a small minority of the klības. According to Syed (2003, p. 108), the vast majority of klïbas were no transsexuals either, but anatomically normal males. She holds the view that klïbas and their modern "descendents", the Hijras, are best to be defined as male transgenders or male femalers (Syed 2003, pp. $109 \mathrm{f}$.). The problem cannot be denied, however, that klības and Hijras alike are shaped by sexual ambiguity. It is difficult or even impossible to separate sex and gender issues strictly from each other, ${ }^{22}$ correlative with the fact that the Sanskrit term linga comprises both di-

19 In R.G. Bhandarkar's the well-known treatise on Vaiṣnavism, Śaivism and Minor Religious Systems, the Sakhībhāvas are classified as "debasement of Vaiṣnavism" and the following disparaging remarks can be found about them: "They deserve notice here only to show that, when the female element is idolized and made the object of special worship, such disgusting corruptions must ensue." (Bhandarkar 1913, p. 86).

$20 K l \bar{l} b a$ is the oldest Indian term for the defective male; the other terms are later synonyms (Syed 2003, p. 66).

21 O'Flaherty (1999, p. 279) and Syed (2003, p. 107) go together by rejecting the widespread translation of klība as "eunuch".

22 Defining "Trans-genders" as human beings rejecting their anatomic and social "Geschlecht", Syed (2003, p. 109) herself is also inconsistent. 
Symbols of Emancipation?

mensions, analogous to the German word "Geschlecht". Hijras do not only reject their masculine gender, but (considerable) numbers of them firmly dismiss their male sex by the ritualised practice of castration. ${ }^{23}$ Due to their sex and gender ambiguity and the practice of sex relations with men, Hijras do not fit to the normative heterosexual framework of their respective societies. They have tried to legitimise their right to exist and expand their scope of agency by corresponding to mythical traditions. Besides the dedication to the goddess Bahucāra Mātā (Reddy 2005, pp. 108 f.), there are the traditions of Mohini and related myths, and even Śiva Ardhanārīśvara, which sanction the identity of the Hijras and empower their life design (Reddy 2005, pp. 89 ff.).

\section{Conclusion: Transgender Symbols and Sex and Gender Normativity}

The fusing androgynous Ardhanārīśvara has been repeatedly praised as a symbol of emancipation, but conveys at best an ambivalent message of human emancipation, the transformative potential being limited by categories that marginalize the female half (Goldberg 2012, p. 135). The androgynous fantasy presupposes that woman is essentially different from man and therefore a complementary force. Thus sexual differences are institutionalized as specific gender roles, which imply a cultural ideology justifying hierarchy and inequality. Far more than presenting an emancipatory symbol, the Ardhanārīśvara is a testimony of conflict (O'Flaherty 1980), a symbol and blueprint for the normative mode of behaviour. Even though there is some evidence that the religious imagery of the feminine, being part of the androgynous godhead, may provide some worthiness, empowerment and agency for women,${ }^{24}$ the social reality of gender roles and gender relations is no more than marginally affected. The same holds true for diverse queer tales concerning transsexuality (like Viṣnu as Mohinī), which are, though subversive from one point of view, conformist from another, because they endorse traditional gender roles and sexual symbolism (Pattanaik 2012, p. 133).

23 The physical genital excision is called nirvan operation and is regarded as the marker of a "real" Hijra; in former times the membership in the Hijra community is said to have been dependent on the dysfunctional male organ, whether by birth or by operation (Reddy 2005, pp. $91 \mathrm{ff}$.). A detailed description of the operation and the ritual relating to it is given by Nanda 1991, pp. 26-29. It must be stated, however, that research connected to this subject is highly controversial regarding the concrete numbers of Hijras who undergo castration.

24 Influenced by the worship of Śakti, in Śaiva traditions women were accorded a degree of respect and autonomy to practice as saints, bhakti-poets, yoginiss, indicating that the normative mode of women can be subverted (Goldberg 2002, p. 146). 
In her study on the third gender in ancient India, Renate Syed (2003, pp. 100 ff.) sharply differentiates between divine androgyny and human hermaphroditism. Androgyny is termed to be a philosophical construct combining maleness and femaleness in perfection and marks divine imagery. On the contrary, hermaphroditism is described as a pathological status of a human being, who deviates from the heterosexual norm regarding sexual anatomy and/or gender role-orientation. Syed points out that the notion of divine androgyny had no positive effect on human sexual deviances. It must be underlined, however, that human sex and gender ambiguities were tolerated in the traditional Hindu society. Though despised and outside the heterosexual norm, the persons concerned were conceded a space in society, and penalties, if existing, were negligible. ${ }^{25}$

In contrast to Renate Syed, Ruth Vanita (2005, pp. $71 \mathrm{ff}$.) stresses the positive social effects of Hindu perceptions of the divine, which are based on the notion that gender is ultimately irrelevant. She refers to the traditional Hindu concept that the human self, representing the divine essence, is genderless: As gender is ultimately unreal, there is no difference between men and women. According to Vanita, the icon of the Ardhanārîsvara signals the ultimate unity of the divine, and the irrelevance of gender. For her, the concept of androgyny seems to correspond to the idea of a genderless self. In modern Hinduism the ancient concept of the genderless self is used to argue for the social equality and freedom for women (Heller 1999, pp. 145 f., 235 f., 302 ff.). Regarding the status of women in Indian history, however, it cannot be stated, that this idea had an effect worth mentioning. Obviously, the mere notion of genderlessness has no effect on divine and human realities alike. Therefore, not the absence of gender, but the fluidity might create new possibilities: "Hindu divinities have not only gender but also sexuality, and this gender and sexuality is fluid. The fluidity allows human gender and sexuality to also be conceived of as ultimately fluid even if socially constricted." (Vanita 2005, p. 78). Jeff Roy goes one step further (2014, p. 2), declaring the mythological references to transgenderism and homosexuality to be a validation of human gender and sexual ambiguity, proving that in "the past, sexually fluid individuals were respected and played significant roles in South Asian society".

Close to these approaches is Sudhir Kakar (2006, p. 37), who interprets the Ardhanārīśvara from the perspective of psychoanalysis. In his opinion, the diminished differentiation between male and female representations in Indian culture, depicting male bodies close to female forms, is reinforced by a religiosity sanctioning man's feminine strivings and raising them to the level of religiousspiritual quest. Following Kakar, in the Hindu culture, feminine traits are joined to masculine ones in superior human beings. Obliterating the difference between

25 In the Manusmrti, one of the most influential texts concerning dharma, the social (and ritual) order, the sexual engagement of a man with another male is judged as "minor offence". To do penance for this "unnatural offence", he has to bathe, dressed in his clothes (Manu 11, 175). 
Symbols of Emancipation?

male and female, however, must not have a bearing on the cultural gender normativity. Furthermore, the ideal of a man integrating feminine traits reflects the androcentric bias of the Ardhanārīśvara and does neither necessarily imply the estimation of effeminate men nor the respect of women.

In summary, it can be stated that there is no reason to idealise the ancient Hindu society regarding the position of transsexual/transgender people and their metaphysical legitimation. There was no golden age for women and queer people respectively in ancient India. Concerning the connectedness alleged between divine symbols and social reality, the case is quite the same with goddess symbols and the status of women or transgender symbols and the status of transgender people. It is as misleading to deduce the high status of people transcending the heteronormativity from the prominence of androgynous or transsexual gods as it is to postulate that rich goddess symbolism automatically brings about a high estimation and dominant social position of women. ${ }^{26}$ Religious symbols are often far away from reflecting or shaping the conditions of human society: Quod licet iovi, non licet bovi. Symbols of god/dess are polyvalent, their significance and interpretation depend on particular contexts and so do their possible social effects (Holte 1979; Heller 1998). Of course, it is also possible that under certain sociocultural conditions religious symbols can evolve into powerful vehicles for emancipation. $^{27}$

At last, what should we do with this multilayered symbolism, leaving behind the mere detached position of historical analysis for the interest in socio-political change? The term transgender can be used in the sense of fusing sex/gender or in the sense of sex-change but also in the sense of non-duality, thus overcoming sex and gender: In metaphysical perspective, sex and gender are to be regarded as unreal, the true self being genderless. Nevertheless, the socio-cultural norm of the binary sex/gender-code is not transcended by these approaches. Applying categories of modern sexual theory on the Ardhanārīśvara, the binary sex/gendercode is subverted. An image connoting fluid sex and gender roles is irritating. Being intersexual or intergender means oscillating between man and woman; and being neither man nor woman means being different and transcending the norms. By disrupting stable categories, the socio-cultural order of sex and gender is put into question. In this light, the image of Ardhanārīśvara as well as Mohinī might be

26 Detailed case studies have made clear that the tendency to assume that divine female imagery positively affects the status of women has "to be balanced by an assessment of the place of Goddess worship within patriarchal forms of society, because worship of a Goddess can also be used to confirm women's subordinate social positions." (King 1997, p. 2).

27 As it is the case, for example, with the goddess Kālī, who was shaped by patriarchal stereotypes of women but can be reinterpreted as a post-patriarchal and liberating model of the feminine: thus a feminist revision of the myths and traits of Kāli can hear her terrifying howls as a demand for equality (Gupta 1994). 
interpreted as symbols of transgender, in the sense of overcoming the rigid gender order. They might be interpreted as symbols of sex and gender ambiguity. As a consequence, however, the traditional name Ardhanārî́vara would not be appropriate any longer. Apart from this, the stereotype of the seductress heckles the wished-for liberating effect of transgender symbolism. It seems to be extremely difficult to discover emancipatory symbols in a world shaped by concepts and images referring to maleness and femaleness, to masculinity and femininity. Nevertheless, our lives are shaped by images based on principles of difference we can't dismiss. Differences of sex and gender rank among the most effective principles of social order. Even the debates on transgender/intergender reveal that the antipodes of man and woman remain the underlying categories of reference. What Hindu god/dess symbolism at least conveys, is the possibility of playing with seemingly fixed realities. By this mode of playing and dubious ambiguity, rigid ideas of one everlasting stable order of social life fade away, overlapped by laughter.

\section{Bibliography}

Baumann, Hermann: Das doppelte Geschlecht. Studien zur Bisexualität. Unveränd. Nachdruck Berlin 1986 [1955].

Bhandarkar, R.G.: Vaiṣnavism, Śaivism and Minor Religious Systems. Strassburg 1913.

Bisshop, Peter: "Śiva”, in: Jacobsen, Knut A. (ed.): Brill's Encyclopedia of Hinduism 1. Leiden / Boston 2009, pp. 741-754.

Bleibtreu-Ehrenberg, Gisela: Der Weibmann: kultischer Geschlechtswechsel im Schamanismus. Eine Studie zur Transvestition und Transsexualität bei Naturvölkern. Frankfurt am Main 1984.

Bowie, Fiona: "Gender Roles", in: Jones, Lindsay (ed.): Encyclopedia of Religion 5. Detroit ${ }^{2} 2005$, pp. 3420-3423.

Brahmānḍa Purāna 4. Ed. By Jagdish Lal Shastri, transl. by Ganesh Vasudeo Tagare (=Ancient Indian Tradition \& Mythology 25). Delhi 1984.

Dimock, Edward C.: The Place of the Hidden Moon. Erotic Mysticism in the VaisnavaSahajiya Cult of Bengal. Chicago / London 1966.

Franke, Edith / Maske, Verena: "Religionen, Religionswissenschaft und die Kategorie Geschlecht/Gender", in: Stausberg, Michael (ed.): Religionswissenschaft. Berlin / Boston 2012, pp. 125-139.

Goldberg, Ellen: The Lord Who is Half Woman. Ardhanārīsvara in Indian and Feminist Perspective. Albany, New York 2002.

Gross, Rita M.: "Androcentrism and Androgyny in the Methodology of History of Religions", in: id.: Beyond Androcentrism. Missoula, Montana 1977, pp. 7-19.

Gross, Rita M.: "Studying Women and Religion: Conclusions Twenty-Five Years Later", in: Sharma, Arvind (ed.): Today's Woman in World Religions. Albany 1994, pp. 327361. 
Symbols of Emancipation?

Gupta, Lina: "Kali, the Saviour”, in: Cooey, Paula M. / Eakin, William R. / McDaniel, Jay B. (eds.): After Patriarchy. Feminist Transformations of the World Religions. Maryknoll, New York, pp. 15-38.

Hayes, Glen A.: “The Necklace of Immortality”, in: White, David G. (ed.): Tantra in Practice. Princeton, New Jersey / Oxford 2000, pp. 308-325.

Hayes, Glen A.: "Sahajiyās", in: Jacobsen, Knut A. (ed.): Brill's Encyclopedia of Hinduism 3. Leiden / Boston 2011, pp. 507-513.

Heller, Birgit: "Gott und Geschlecht. Aspekte hinduistischer Gottes- und Menschenbilder", in: Zeitschrift für Missions- und Religionswissenschaft (82/2) 1998, pp. 107-116.

Heller, Birgit: Heilige Mutter und Gottesbraut. Frauenemanzipation im modernen Hinduismus. Wien 1999.

Holte, Ragnar: "Gottessymbol und soziale Struktur”, in: Humanitas religiosa. Festschrift für Haralds Biezais zum 70. Geburtstag. Stockholm 1979, pp.1-14.

Johnson, Matt: "Transgender Subject Access: History and Current Practice", in: Cataloging \& Classification Quarterly (48/8) 2010, pp. 661-683.

Johnson, William John: "Sakhībhāvas", in: A Dictionary of Hinduism. Oxford et al. 2009; available at: http://www.oxfordreference.com/view/10.1093/acref/9780198610250.00 1.0001/acref-9780198610250-e-2150 [09.01.2017].

Kakar, Sudhir: "Culture and Psychoanalysis. A Personal Journey", in: Social Analysis (50/2) 2006, pp. 25-44.

King, Karen L. (ed.): Women and Goddess Traditions. In Antiquity and Today. Minneapolis 1997.

King, Ursula: “Gender Studies. An Overview”, in: Jones, Lindsay (ed.): Encyclopedia of Religion 5. Detroit ${ }^{2} 2005$, pp. 3296-3310.

Kramrisch, Stella: The Presence of Siva. Princeton, New York 1981.

Lang, Sabine: Männer als Frauen - Frauen als Männer. Geschlechtsrollenwechsel bei den Indianern Nordamerikas. Hamburg 1990.

Manusmrti. The Laws of Manu. Transl. by Georg Bühler (= The Sacred Books of the East 25). Delhi et al. 1988.

McDaniel, June: "The Role of Yoga in Some Bengali Bhakti Traditions: Shaktism, Gaudiya Vaishnavism, Baul, and Sahajiya Dharma”, in: The Journal of Hindu Studies (5/1) 2012, pp. 53-74.

Nanda, Serena: Neither Man Nor Woman. The Hijras of India. Belmont, Calif. 1991.

O'Flaherty, Wendy Doniger: Women, Androgynes, and Other Mythical Beasts. Chicago / London 1980.

O'Flaherty, Wendy Doniger: Śiva. The Erotic Ascetic. Oxford et.al. 1981 [= Asceticism and Eroticism in the Mythology of Śiva, 1973].

O'Flaherty, Wendy Doniger: Splitting the Difference. Gender and Myth in Ancient Greece and India. Chicago / London 1999.

O'Flaherty, Wendy Doniger: “Androgynes”, in: Jones, Lindsay (ed.): Encyclopedia of Religion 1. Detroit 2005, pp. 337-342.

Pattanaik, Devdutt: The Man Who Was a Woman and Other Queer Tales from Hindu Lore. New York / London 2012.

Ramet, Sabrina Petra: Gender Reversals and Gender Cultures. Anthropological and Historical Perspectives. London / New York 1996. 
Reddy, Gayatri: With Respect to Sex. Negotiating Hijra Identity in South India. Chicago / London 2005.

Roscoe, Will: Changing Ones: Third and Fourth Genders in Native North America. New York 2000.

Roy, Jeff: “Unveiling Koovagam”, in: World Policy Journal (31/2) 2014, pp. 91-99.

Sigusch, Volkmar: Sexualität. Eine kritische Theorie in 99 Fragmenten. Frankfurt am Main 2013.

Śiva Purāna 1. Ed. by Jagdish Lal Shastri, transl. by a Board of Scholars (Ancient Indian Tradition \& Mythology 1). Reprint Delhi et al. 1996.

Suthrell, Charlotte: Unzipping Gender. Sex, Cross-Dressing, and Culture. Oxford et al. 2004.

Syed, Renate: "Tṛtīyā prakṛti. Das 'Dritte Geschlecht' im Alten Indien”, in: Asiatische Studien (= Ètudes Asiatiques) (57/1) 2003, pp. 63-120.

Vanita, Ruth: Love's Rite. Same-Sex Marriage in India and the West. New York / Houndmills, U.K. 2005.

Vanita, Ruth: "Sexuality", in: Jacobsen, Knut A. (ed.): Brill's Encyclopedia of Hinduism 4. Leiden / Boston 2012, pp. 740-753.

White, David Gordon: Kiss of the Yoginī. "Tantric Sex" in its South Asian Contexts. Chicago / London 2003.

Yadav, Neeta: Ardhanārīśvara in Art and Literature. New Delhi 2001.

\section{Internet sources}

Prabhakar, Jyothi: "Was homosexuality, transgenderism part of our culture?", in: The Times of India, 13.12.2013, available at: http://timesofindia.indiatimes.com/life-style/ spotlight/Was-homosexuality-transgenderism-part-of-our-culture/articleshow/27241 373.cms? [14.04.2016].

Quora: What is the story behind Shiva and Mohini?, available at: https://www.quora. com/What-is-the-story-behind-Shiva-and-Mohini [14.04.2016].

\section{Index of Illustrations}

Illustration 1: (C) Dinodia Photos / Alamy Stock Photo, available at: http://de.alamy.com/ stock-photo-ardhanarisvara-beside-his-bull-niche-on-the-southern-wall-of-the-mu khamandapa-124477094.html [09.01.2017].

Illustration 2: Religionskundliche Sammlung, Philipps-University of Marburg (shelf no.: B-Kp 154 03; original received 1994 from Christa Pieske, Lübeck; trough the intermediary of Dr. Vanja, Berlin).

Illustration 3: () Dinodia Photos / Alamy Stock Photo; available at: http://www.alamy. com/stock-photo-lord-vishnu-in-form-of-mohini-dancer-at-channakesava-vishnutemple-83606380.html [09.01.2017].

Ao. Univ.-Prof. Mag. Dr. Bakk. Birgit Heller, Institut für Religionswissenschaft, Universität Wien, Schenkenstraße 8-10,1010 Wien, Austria, birgit.heller@univie.ac.at 
Symbols of Emancipation?

Citation: Heller, Birgit: "Symbols of Emancipation? Images of God/dess, Devotees and Trans-sex/gender in Hindu Traditions", in: Heller, Birgit (ed.): Religion, Transformation and Gender. (J-RaT 2017 / 2), pp. 235-257.

Datum der Publikation: 02.10.2017 